The Geneva Papers on Risk and Insurance, 19 (No. 70, January 1994), 46 - 59

\title{
Ex Post Control of Insurance in Belgium
}

\author{
by Herman Cousy* and Hubert Claassens*
}

\section{The context}

Private Insurance is on the move. Insurance markets, insurance undertakings, insurance distribution patterns, even insurance products are subject to various and profound changes. So is the regulatory framework. Member States of the European Economic Community are led to drastically change their supervisory legislation (see further on, sub No. 5) as well as their legal regulations concerning the distribution of insurance, ${ }^{1}$ concerning accounting of insurance undertakings, ${ }^{2}$ even concerning insurance contracts law. ${ }^{3}$

This paper focuses on some aspects of an important modification which recently has been or shortly will be introduced into the supervisory legislation of most of the E.E.C.Member States and which is commonly referred to as the change from "ex ante supervision" (in French: "contrôle a priori") to "ex post supervision" (in French: "contrôle a postériori"), a change which was set in motion by the so called "third generation" E.C. insurance directives.

The debate about the respective merits of the one and the other type of insurance supervision must be projected against the background of the tension which inevitably exists between the pro's and con's of any type of insurance regulation and supervision. On the one hand there is indeed the admitted necessity and desirability of some kind of regulation in view of the problems related to the phenomenon of "informational asymmetry". As is well known, informational asymmetry is said to be particularly problematic in the field of insurance because of the "inversion of the production cycle" phenomenon. For the policyholder who needs to appreciate the reliability and soundness of the insurer, whom he entrusts with the premium in return for a possible later payment, it is very difficult to

* Professor of Law, University of Leuven.

1 In order to carry out the Recommendation of the Commission (92/48/EEC) of 18 December 1991 (O.J. 28 January 1992).

2 Council Directive (91/674/EEC) of 19 December 1991, (O.J. 31 December 1991).

3 As was very recently the case in Belgium, where the old insurance contract law act of 11 June 1874 was replaced by a new act of 25 June 1992 . 
acquire knowledge about the insurer's solvency.$^{4}$ It therefore seems to be more efficient to entrust the information gathering to a supervisory authority. Some find another justification for insurance supervision in the fact that insurance is a business affected with a public interest. Such is the case because any shortcoming or failure of an insurer threatens to affect not only the immediate creditor but also the community at large. ${ }^{5} \mathrm{~A}$ business affected with a public interest is forced to operate in an environment more restrictive than business in general.

On the other hand economic theory warns us against the undesirable side effects, such as market concentration, limitation of product differentiation, ${ }^{6}$ to which economic regulation may give rise. This wellknown discussion will not be repeated here. It is interesting however, to note that very similar arguments will be encountered in the debate about the respective merits of the two types or models of insurance supervision which will be described and analyzed hereafter.

After some introductory remarks concerning terminology and classification of the different types or models of insurance supervision, this paper will first very briefly describe the way in which the ex ante/ex post discussion was introduced by the E.C. directives, and then concentrate upon the case-study of the rather remarkable way in which Belgian legislation has recently interpreted and implemented the new principle of "a posteriori control" by its regime of "contrôle de la rentabilité". While intending to remain mainly descriptive, the paper will also raise some questions both as to the substantive merits of the described system and as to compatibility of this system with the E.C. (third generation) directives. The study of the Belgian case will also lead to some more general considerations about supervisory policies and methods.

\section{Models of supervision}

There appears to be some unclarity, even confusion about the classification, or in any event about the terminology with respect to insurance supervision. Various (and varying) criteria are used to classify the different categories and models of insurance control.

In French and German terminology "le contrôle financier" or "Finanzaufsicht" is often opposed to the "contrôle matériel" or "materielle Staatsaufsicht". When used in this way,

${ }^{4}$ It is interesting to notice how this argument is also made in the Court of Justice decision of December 4, 1986 in the case Commission v. Germany, where the court says: "Similarly, it is as a rule very difficult for a person seeking insurance to judge whether the likely future development of the insurer's financial position and the terms of the contract, usually imposed by the insurer, offer him sufficient guarantees that he will receive payment under the policy if a claimable event occurs".

${ }^{5}$ Mehr and Cammack, Principles of Insurance, 1980, p. 668. Also this idea is not absent in the European Court of Justice decision of December 4, 1986 in the case Commission v. Germany, where the court considers: "It must also be borne in mind, as the German Government has pointed out, that in certain fields insurance has become a mass phenomenon. Contrats are concluded by such enormous numbers of policy-holders that the protection of the interests of insured persons and injured third parties affects virtually the whole population".

${ }^{6}$ See Faure, "Ongevallenpreventie door efficiënte aansprakelijkheidsregelen in verzekeringspolissen op competitieve verzekeringsmarkten", Het verzekeringsarchief, 1993, 3 and the references to Finsinger "European Integration of Insurance Markets. Preliminary but novel perspectives", Working Paper Universität Lüneburg No. 75, ISSN 0176.7275, October 1989; to Finsinger, J. and Schmid, F. A., "Prices, Distribution Channels and Regulatory Intervention in European Insurance Markets", Working Paper, University of Vienna, Business Economics Institute, June 1992 and to Adams, M., Ökonomische Analyse der Gefährdungs- und Verschuldungshaftung, Heidelberg, Deckers Verlag, $1985,215-216$. 
the term "financial supervision" refers to the supervision of solvency of the company as well as of the technical provisions (and possibly of the matching assets) whereas the term "contrôle materiel" refers to the supervision of policy conditions and insurance rates. ${ }^{7}$

When juxtaposed to "economic supervision", the term "financial (in that case, also called technical) supervision" is the control which aims at verifying the solvency of the undertaking as well as the legality of its operations. The object of "le contrôle economique" is the organization of the insurance market $^{8}$ and the orientation of the insurance undertaking's investments. When "financial supervision" is distinguished from "legal supervision", this last term refers to the verification of the conformity of the policy conditions with the compulsory provisions of the applicable law, whereas the financial supervision englobes, in that hypothesis, the supervision of solvency, reserves and rates as well. ${ }^{9}$

\section{Object and level of control}

While shaping a regulatory framework for insurance, states have to make important choices as to the object, the level, the techniques and the location of their supervision. E.C. Member States will be obliged to reconsider some of their policies on this matter.

On the basis of the object of control, insurance supervision may be more or less complete and relate to one or more of the following matters: solvency, solidity (including quality of management, structure of shareholding), technical provisions, matching assets, rates, insurrance conditions, prices, trade practices, distribution patterns, non legal disputes, etc. Member States (like Belgium) who used to practice a fairly complete supervision of solvency, of technical provisions, of rates and of insurance conditions (thus combining financial, economic and "material" control) will be obliged by E. C. directives to fundamentally reconsider their system and to abolish at least some aspects or goals of their existing system of insurance supervision. A particular question will be whether there will be any supervision of insurance conditions. In a number of E.C. Member States some kind of administrative control upon policy conditions has traditionally been organized in the context of the "contrôle matėriel" (materielle Staatsaufsicht). At the moment where the E.C. directives impose the abolition of any ex ante and any systematic supervision, the time is ripe to reflect upon the desirability of keeping in place any (be it "ex post") administrative supervision of the legality of policy wordings and conditions.

On the basis of the level of control, supervision can be specific to insurance or extend to, say, other financial institutions (cf. the blurred distinction between banks and insurance companies in the context of "bancassurance") or even to all producers (like in the case of a general price control system). Inside the field of insurance, control mechanisms can differ between branches (e.g. life and non-life). Inside the insurance company the supervision can be either global (aiming at the financial soundness of the company - or the group of companies - as a whole) or be specific for definite "classes of insurance" or "products" or "group of products". In other words, the financial supervision can be organized (only) at the level of the global financial soundness (solvency) of the company, or (also) at the level of the

${ }^{7}$ Compare Hohlfeld, "Die Zukunft der Versicherungsaufsicht nach Vollendung des Binnenmarktes", Versicherungsrecht, 1993, p. 144.

8 Picard et Besson, Les Assurances Terrestres en droit français, T. II, Les entreprises d'assurances, Paris, No. 1977, No. 632, p. 161.

9 O. C. D. E., Contrôle de l'assurance privé en Europe, 1963, p. 10. 
premium rates. Whereas the solvency supervision necessarily concerns the undertaking as a whole, supervision of technical provisions and especially supervision of premium rates will almost necessarily be organized at the level of certain categories of insurance classes. If E.C. directives are definitely opposed to ex ante control of tariffs and insurance conditions, they are less clear as to what kind of ex post insurance control is compatible with the directive. It is therefore interesting to study the Belgian system of "contrôle de rentabilité" which is based on the control of the premium tariffs per group of products.

With respect to the ways and techniques of insurance supervision, numerous distinctions can be made: supervision of documents versus "in situ" inspection, systematic and non-systematic inspection, general control or random testing, the exercise of the "ombudsman" function and ... the distinction between ex ante or ex post supervision!

Finally, as one knows, E.C.-law distinguishes on the basis of the degree of centralization or of location and has established on that basis the well-known distinction between "home country control" and "risk country control". This last distinction is not the object of our present preoccupation. ${ }^{10}$

\section{Two "cultural" approaches}

In many instances, the choices to be made reflect a more fundamental option between two approaches or even two "cultures" of insurance and insurance supervision.

We think that a basic distinction exists between the undertaking-oriented approach and the product-oriented approach. Insurance regulation (and supervision) either focuses on the soundness of the insurance company or on the contents and price of the insurance product. In the first approach (sometimes called "financial approach") the accent is upon the solvency, the professional ability and trustworthiness of the directors and actuaries, and even on the identity of the shareholders of the company. In the second approach the supervision concentrates on the insurance conditions and on just and sufficient premium rate levels. In this way, the quality of insurance business is regulated and supervised, either at producer level, or, in the other type, more at product level.

One can also distinguish, as Reimer Schmidt has done, ${ }^{11}$ between the more "economic" approach of supervisory authorities toward the insurance business and the rather "legal" approach. Prof. Reimer Schmidt thought that at present days a shift can be observed from the preoccupation for the performance of the contract to a more attentive attitude toward the formation of the contract. In the contemporary (more economic) approach there is in some ways a shift of attention from the protection of the interests of the creditor (the insured, the beneficiary) to those of the debtor (the insurer). This very (re)orientation of the attention toward the "supply" side is also found in the reasoning which lies at the basis of the E.C. insurance directives. The very first paragraph of the preamble to the 2 nd non-life directive of June $22,1988,{ }^{12}$ considers that in order to achieve the objective of developing the

${ }^{10}$ See among others Marette, "Contrôle de l'assurance et marché unique", in L'Europe de l'assurance, Maklu-Academia-Bruylant, 1992, 85-109.

${ }^{11}$ Reimer Schmidt, Kernfragen der Finanzaufsicht über Versicherungsunternehmen, Versicherungsrecht 1990, Heft 25, 1 September 1990, p. 921.

12 For a more precise identification and a more detailed description of the directive, see hereafter, No. 5. 
internal insurance market, it is desirable to make it easier for insurance undertakings (having their head office in the Community) to provide services in the Member States, thus making it possible for policyholders to appeal not only to insurers established in their own country, but also to insurers established in other Member States. ${ }^{13}$

In some ways the distinction between the different approaches to insurance and insurance supervision corresponds with another, even more fundamental distinction between two insurance cultures or traditions, the continental-European tradition and the AngloSaxon tradition, or to say it in the terms which were introduced by Michel Albert, the distinction between the "alpine" and the "maritime" models of insurance. ${ }^{14}$ Relating the distinction between two insurance models to two forms of capitalism, ${ }^{15}$ the author rightly points out that this opposition between philosophies was at the basis of many a debate concerning the future of insurance regulation in Europe. In the "alpine" model, insurance is basically seen as a mechanism of solidarity characterized by a far-reaching mutualisation between the insured, and by the idea of a community of interests between insurer and insured. Typical is the way in which the administrative control of motor vehicle liability insurance is organized: in principle one single non-segmented premium tariff is imposed by the supervisory authority. 16

In the "maritime" model, insurance is situated in the sphere of finance and is entirely submitted to the laws of the market place. The insurance broker plays a far more prominent role than the insurer. Even in automobile insurance premium tariffs are free. Selectivity in underwriting and segmentation of premium rates are the rules of the game.

The E.C. directives, at least the so-called "third generation" directives, appear to have been inspired by the "maritime" model of insurance supervision. But, as will appear from the following description, the way to the third directives has been hesitating ${ }^{17}$ in such a way as to make the gradual introduction of another philosophy of supervision rather difficult to identify.

${ }^{13}$ In his highly interesting article on myth and reality in the consumer protection - aspects of the internal insurance market ("Le consomateur face au marché unique de l'assurance: mythe et réalité", Droit de la Consommation. Consumentenrecht, 1992, 1080-1119, spec. 1090-1095) Bernard Dubuisson rightly points out that the third generation directives are built on the conviction that the modification of the supply conditions will inevitably change market conditions and that the factors influencing demand are almost systematically neglected in the European harmonization process. Yet these factors play an important role in the decision of the policyholder. Think for example of the taxation, of the matrimonial law aspect, of the social law with respect to 2 nd and 3 rd pillar of pension schemes, etc.

The recent Court of Justice decision in the Bachmann-case (January 28, 1992) has clearly illustrated the necessity for harmonizing the fiscal environment of the life insurance. But there are at the side of the policyholder and the insured many more issues which require attention, such as the harmonization of the insurance contract law. In our view these aspects are equally vitally important for the creation of a truly single market.

${ }^{14}$ Albert, M., "L'avenir de l'assurance: Modèle alpin ou modèle maritime", Risques, Les cahiers de l'assurance, 1991.

15 Comp. Albert, M., "Capitalisme contre capitalisme", L'Expansion, 15-12-1990.

${ }^{16}$ Such was the case in Belgian law until a "deregulated" regime was introduced by a Royal Decree of 3 February 1992. Tariffs are now free except for minimum "pure" premiums (the pure premium being defined as the part of the commercial premium which intended to cover the risk).

${ }^{17}$ See about the idea of the "détour" by the second directives: Claassens, H. en Cousy, H., "Le cadre général des directives de la troisième génération", in L'Europe de l'assurance, 45-70. 


\section{The wanderings of the E.C. directives}

It may be useful to briefly point out the way in which the three successive (generations of) E.C. coordination directives have laid down the principles which should guide Member States in the organization of their insurance supervision systems. ${ }^{18}$

In order to facilitate the taking-up and pursuit of the insurance business and to ensure at the same time adequate protection for insured and third parties in all the Member States, the first directive concerning direct insurance other than life (73-239-EEC of 24 July 1973) and the first life insurance (79-267-EEC of 5 March 1979) coordinate the national provisions relating to the financial guarantees required for insurance undertakings. Supervision in each Member State is extended to all the classes of insurance, through a generalized system of official authorization, the conditions for the granting and withdrawal of which are coordinated.

Member States are required to supervise the financial position of the undertakings in close collaboration. ${ }^{19}$ They shall require each authorized undertaking (in their territory) to establish sufficient technical reserves ${ }^{20}$ (the coordination of the legislations on these matters, such as the determination of categories of investments and the valuation of assets, being at that stage postponed until subsequent directives), they shall require each undertaking in their territory to establish over and above technical reserves, an additional reserve, to be known as the solvency margin, in order to provide against business fluctuations ${ }^{21}$ and they shall require undertakings to produce an annual account ${ }^{22}$ and to render periodically the returns together with the statistical documents. ${ }^{23}$

With respect to general and special policy conditions, tariffs and any other documents necessary for the normal exercise of supervision, the first coordination directives do not prevent Member States from requiring (prior) approval of the general and special policy conditions, tariffs and any other document (art. 8 and 10, first non-life and first life dir.). The coordination of provisions regarding these matters and even the rules concerning the applicable law have are not treated by the first directives.

\section{Developing the internal insurance market}

The basic idea of the second non-life directive (88/357/EEC of 22 June 1988) and the of second directive on direct life insurance $(90 / 619 / \mathrm{EEC}$ of 8 November 1990) is that in order to develop the internal insurance market, one must make it easier for insurance undertakings having their head office in one Member State to provide services in other Member States. To achieve this purpose, the two first cooperation directives are supple-

18 We will do so by making a kind of summary of the considerations which, at the time, have guided the European law makers, and which are laid down in the preamble to the directives.

${ }^{19}$ Art. 13, first non-life dir.; art 15, first life dir.

20 Art. 15, first non-life dir.; art 17 first, life dir.

${ }^{21}$ Such margin shall be related to the overall volume of business of the undertaking and be determined by reference to two indices of security, one based on premiums and the other on claims (art. 16, first non-life dir., art. 18, first life dir.). A gradual system of sanctions is provided for the case the undertaking cannot live up to its obligations (art. 20, first non-life dir.; art 24, first life dir.).

22 Art. 19, first non-life dir.; art 23, first life dir.

${ }^{23}$ Art. 19, first non-life dir.; art 23, first life dir. 
mented with provisions which "clarify the powers and means of supervision of the supervisory authorities". and also with specific provisions regarding the taking-up. pursuit and supervision of activity by way of freedom to provide services. ${ }^{24}$

The second directives introduce important new rules with respect to financial supervision.

As far as large risks (active consumers in life insurance) are concerned, the procedures regarding financial guarantees "may be relaxed". ${ }^{25}$ Whereas in the case of large (non-life insurance) and active consumers (life insurance), the technical reserves should be subject to the rules and supervision of the Member State in which the insurer is established. in the case of mass risks (passive consumer) the Member State of provision of services. can, if he wishes. submit the technical reserves to special protection. ${ }^{26}$

Under the second generation directives Member States can maintain laws or regulations concerning approval of general and special policy conditions. of forms and other documents. and of premium scales. insofar as the rules of the Member State of establishment are not sufficient to achieve the necessary level of protection. ${ }^{27}$ With respect to large risks (active consumers in life insurance) however, Member States cannot require approval or systematic notification of the said conditions. documents and premium scales. They may only require non-systematic notification. Compliance with laws and regulations may not be constitute a prior condition for an undertaking to carry out its activity. ${ }^{28}$

\section{Completing the internal market}

The third non-life directive (92/49/EEC of 18 June 1992) and the third life directive (92/36/EEC of 10 November 1992) aim at completing the internal market in direct insurance. In order to achieve this goal. all policyholders. irrespective of their status. size or the nature of the risks to be insured. must be enabled to appeal to any insurer with a head office in the Community, while adequate protection must be guaranteed to them. The approach consists in bringing about such harmonization as is essential. necessary and sufficient to achieve the mutual recognition of authorizations of prudential control systems. thereby making it possible to grant a single authorization ("licence unique") throughout the Community and apply the principle of supervision by the home Member State ("contrôle unique ").

Henceforth the home Member State authorities will be responsible for monitoring the financial health of the insurance undertaking, which includes their state of solvency. the

\footnotetext{
${ }^{24}$ Considerations 4 in both directives: art. 10. 2nd non-life dir. and art. 5, 2nd life dir. As is well known the 2 nd generation directives install freedom to provide (insurance) services at two speeds: on the one hand a true such freedom for large risks. that is policyholders which by virtue of their status. their size or the nature of the risk to be insured, do not require special protection of the State in which the risk is situated (in non-life insurance) and for active consumers. that is those policyholders who take the initiative to entering into a commitment in another State and thus place themselves under the protection of the legal order of that State (in life insurance).

25 Art. 22. 23. 2nd non-life dir.: art. 24 and 22. 2nd life dir.

${ }^{26}$ See considerations No. 12 and 14. 2nd non-life directive: and No. 10. 2nd. life directive.

27 Art. 18. 2nd non-life dir.: art. 19. 2nd life dir.

28 Art. 18. 2nd non-life dir.: art. 19. 2nd life directive. However prior notification and approval of premium rates can be required. even for large risks. "as part of a general price control system."
} 
formation of technical "provisions" 29 and the coverage of technical provisions by matching assets. The rules governing the spreading, localization and matching of the assets are coordinated in order to facilitate the mutual recognition.

With respect to insurance contracts, the third directives consider that the harmonization of contract law is not a prior condition for the achievement of the internal market in insurance. But conflict of laws rules are introduced which do allow Member States to impose the application for their own law for policyholders (like mass risks in non-life insurance and active conscumers in life insurance), ${ }^{30}$ who require special protection.

The (for our proposes) most important aspect of the third generation directives is of course that they hold a condamnation and indeed a radical prohibition of any system of ex ante control of conditions and premium rates. The new rule is as a "basso continuo" omnipresent in both the third directives but it is clearly and explicitly formulated e.g. in article $6, \S 3$ of the third non-life directive: "Member States shall not, however, adopt provisions requiring the prior approval or systematic notification of general and special policy conditions, scales of premiums and forms and other printed documents which an undertaking intends to use in its dealing with policyholders. Member States may not retain or introduce prior notification or approval of proposed increase in premium rates except as part of general price control systems". Member States, it is admitted in the preamble to the said directive, ${ }^{31}$ must be able to ensure that the insurance products and documents used comply with the applicable legal provisions, specifically the legal provisions protecting the general good. But the employment of a system of supervision may not constitute a prior condition for carrying on insurance business and in particular systems for prior approval of policy conditions do not appear to be justified. It is therefore necessary to provide for other systems better suited to the requirements of an internal market which enable every Member State to guarantee policyholders adequate protection (end of quotation).

The ruling of the third directive thus prohibits the (especially in the Member States which follow the alpine tradition of insurance) widely spread "système de contrôle matériel a priori", but no clear indications are given as to how this model of supervision should be replaced. The recently introduced Belgian system of "contrôle de la rentabilité" offers an interesting point of comparison.

${ }^{29}$ Whereas at the stage of the first directives the harmonization of the rules with respect to technical provisions had been postponed until a later stage, the third non-life directive announces that this harmonization is deemed to have been already effected by the directive $91 / 674 / \mathrm{EEC}$ of 19 december $199 \mathrm{l}$ concerning annual accounts of insurance undertakings. With respect to life insurance on the other hand, rules concerning the mathematical provisions in life insurance are not really harmonized, the third directive limiting itself to harmonizing the so called "actuarial principles", governing the calculation of technical, especially mathematical provisions (art. 18, 3rd life dir. replacing art. 17 of the first 1979 life directive).

30) It is for the Member State in which the risk is situated to ensure that there is nothing to prevent the marketing within its territory of all insurance products offered for a sale in the Community as long as they do not conflict with the legal provisions protecting the general good (consid. No. 19 and 20, 3rd. non-life dir.; cons. No. 20 and 2 l, 3rd life dir.).

31 Introductory "wherenas" No. 20, O.J. I1.8.92, No. L 228/3. 


\section{The Belgian answer (law of 19 July 1991)}

The Belgian Insurance Supervision Act of 9 July 1975 has extended state - supervision, previously only existing in certain classes of insurance, to all insurance branches. The direct occasion for the introduction of this new legislation was of course the first coordination directive with respect to direct insurance other than life insurance which had been issued on 24 July 1973. Wheras Member States were left with a lot of freedom as to how to organize the other aspects of supervision, Belgian legislation has followed and respected the continental (or "alpine") tradition of a fairly "complete" model of supervision: combination of the requirements of a prior authorization, a solvency margin and the calculation and accounting of "technical reserves", the imposition of stringent (minimum as well as maximum) investment rules with respect to the matching assets and finally elaboration of a system of "contrôle materiel", including the requirement of prior approval of premium rates and of insurance conditions. In Belgium ${ }^{32}$ the July 1, 1994 dealine was not awaited for to abandon this system of "contrôle a priori" and to replace it by a rather remarkable system of its own, which deserves some more detailed attention. ${ }^{33}$

By a legislative act of 19 July 1991, the Insurance Supervision Act was already amended, not (or not only) in an effort to anticipatorily implement the third directives, but with the explicit goal to modernize and in fact reorient the Belgian supervisory model. The manoeuvre is commonly referred to as the replacement of a system of "contrôle a priori" by a "contrôle a posteriori", which in reality is a rather poor description of a broader legislative manoeuvre. The change of supervisory policy does indeed concern the legal (supervision of policy conditions) as well as the financial (relating to solvency, technical provisions and premium rates) supervision. Here follows a brief description.

\section{The control of profitability}

The newly introduced system of insurance supervision is called "contrôle de la rentabilité" ("profitableness"). ${ }^{34}$ The central basic idea of the system is that the financial soundness and the long-term solvency of an insurance company depend to a very large degree upon the quality and sufficiency of its premium rates (or scales) ("tarif des primes"). Therefore the supervision of premium rates is to be, or rather to remain, the centrepiece of the financial supervision. The big difference with the old system is that the supervision of premium rates will now be better organized, and that approval of them will not constitute a prior condition for an undertaking to carry on its business.

A second basic idea is that the required "rentabilite" must be realized (and verified), not on the level of the entire company or of any distinct "administration" (like life assurance, motor vehicle liability insurance), but on the level of each "product" or group of

32 Compare the system of "contrôle par sondage" introduced in France by a "dècret" of 28 June 1991, see Vathaire, A., "Souplesse accrue du contrôle des assurances", L'Argus, 1991, 2112.

${ }^{33}$ The legislative reorganization also changed many other aspects of insurance supervision besides the ex ante and ex post character, see Delporte, J. M., "Le contrôle des entreprises d'assurances", Droit des Affaires, Ondernemingsrecht, No. 26, 35.

34 The legal basis for the new regime of "contrôle de la rentabilite" is to be found in article 21 bis of the Act on Insurance Supervision (as introduced by the Act of 19 July 1991). According to this provision the Office of Insurance Supervision can require an undertaking to raise its premium rate scales in case of deficit. Further details of the principles and methods are laid down in communications of the Office of Insurance Supervision ("Office de Contrôle des Assurances"). 
products. The idea is that no single (insurance-) product should be sold at a loss. Whereas insufficient rates do not immediately threaten the companies' solvency, it is considered unjust that one category of insured systematically bear the losses suffered by others. A close and systematic inspection of the profitableness of all the different rate fares which the company applies to different products is also considered to be the only and certainly the best way for early discovery of problems. Under a system (like the old one) where the supervisory authority can only take measures in cases where the solvency margin of an insurance company is threatened, measures will often come too late. Finally, a close and continuous monitoring of the profitableness of the company "per product" is deemed to be a good financial management practice, which each undertaking should apply, independently from any State supervision. Inducing the financial managers of insurance companies to organize such a system will, so it is generally thought, be at least one beneficial effect of the newly introduced supervisory model.

In principle the evaluation of the "rentabilite" is based on the yearly results but the evolution over several years will constitute an important element of appreciation. In the non-life insurance, statistical data are collected on 93 (!) different product ("products" being a further subcategory of the classes of insurance in the annex to the first non-life directive). For the purpose of the evaluation of their profitableness, the products are grouped in 33 "groups of products". In life insurance 13 different products are distinguished and spread out over 7 "groups" for purposes of evaluation.

The evaluation of the profitableness of group of products implies that, in a first movement, all costs are spread out over the different columns of products and allocated to them. Another important principle is that investment income stemming from the equity capital (non-technical investment income) is not taken into account in the calculation of profitableness per product category but those earnings are taken into account in the calculation of the global return rate which will be applied to technical reserves of any given category of products. ${ }^{35}$ Neither are non-realized value fluctuations. In principle the „profitableness”

35 It is also important to point out the way in which the investment income (and charges) will be calculated. This calculation is done per group or category of products and according to the following formula :

Investment income $(i)=\frac{\text { global investment income }}{\text { average total assets }} \times$ average provisions $(i)$

\section{global investment income}

income on all assets including the so-called non-technical but with the exclusion of income from life assurance related to investment funds (unit-linked)

\section{average total assets}

totality of the average assets $\left(\frac{\text { assets begin }+ \text { assets end }}{2}\right)$ but with the exclusion of the assets stemming from life assurance related to investment funds

\section{average technical provisions (i)}

the average $\left(\frac{\text { begin }+ \text { end }}{2}\right)$ provisions in any category of products $i$. 
will be examined at the level of what is called the "gross technical-financial balance", 36 which means that reinsurance results and non-technical earnings are not taken into account. ${ }^{37}$

\section{Handling the control of profitability}

The good functioning of the system of "contrôle de rentabilité" implies the correct handling of at least three problems of a more practical nature.

First, the supervisory authority needs a very detailed and precise statistical information in order to be able to monitor the ratios and equilibria. A sophisticated software programme has been elaborated by the Office of Insurance Supervision and communicated to all undertakings which are invited to transmit all requested data by "diskette".

A second and very important (not only practical but also theoretically interesting) question relates to the degree of segmentation: how far will one go in the breakdown of insurance classes into "products" or "groups of products" for which the equilibrium must be realized? Quite delicate is the choice which has to be made at this point, since extreme segmentation is contrary to the basic idea of mutuality. In practice, the Office of Insurance Supervision has elaborated a fairly detailed classification of 13 different categories (or states) in life assurance and of 93 different products (to be bundled in 33 groups of products) in non-life insurance. ${ }^{38}$

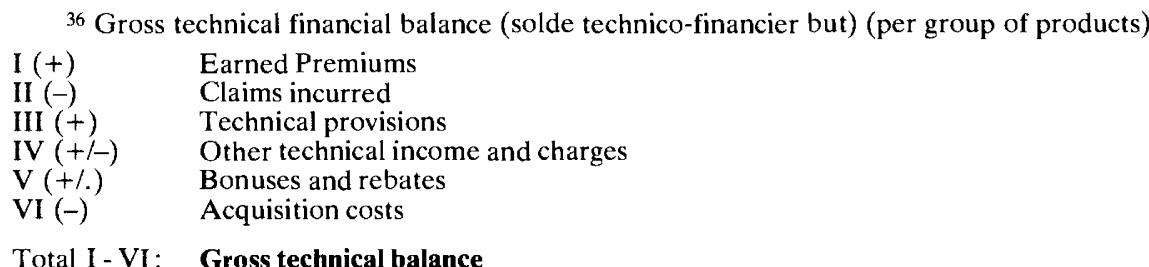

VII (-) Administration costs

Total I - VII : Gross balance (before financial income)

VIII ( + Investment income

IX (-) Investment charges

Total I - IX: Gross technical - financial balance

$X \quad$ Outgoing reinsurance (not split up)

Total 1 - X: Net technical - financial balance

XI Allocation of non-technical earnings

XI1 Allocation of non-realized capital gains

XIII Allocation of non-realized capital losses

37 However, as explained in the communication D 102, in exceptional circumstances (e.g. exceptionally high amount of claims in any given year) the net technical-financial balance (after imputation of the results of outgoing reinsurance) can be taken into account. It is added that outgoing reinsurance will, in the long run, in most cases constitute an expense and thus negatively influence the technical-financial result.

38 Whereas available statistical data must be given per product, profitableness will be evaluated and judged per group of products. If problems come to the surface, the supervisory authority will be able to trace down the cause or origin of the problem on the basis of the statistical data per product. 
A third problem relates to the measures which the Office of Insurance Supervision can take when observing a case of non-profitableness. As mentioned above, the supervisory authority can oblige the insurance company to raise its premium rates. In practice, however, this is intended to be the "ultimum remedium". Other measures can be imposed, like a better management of the operation costs, the modification of insurance conditions, of the investment policy, or of the reinsurance practice.

\section{1. "A posteriori" supervision of insurance conditions.}

Belgium used to have a regime of "contrôle matériel a priori" of insurance policy conditions. Prior approval of general and special insurance conditions by the Office of Insurance Supervision was required before the policy in question could be brought into the market.

Even apart from the E.C. directives aiming to eliminate such prior approval requirements, experience had already shown the many disadvantages of the system.

Theoretically, the Office of Insurance Supervision was only mandated to verify the conformity of the insurance conditions to the laws and regulations, but some of the legal rules concerning insurance policies are formulated in such general terms that their implementation did in fact allow the supervisory authority to exercise a practically discretionary power. On the other hand the prior approval could also be (mis-)used by some insurers as a "soi-disant" blessing or even as a quality label. Prior approval, so was claimed by consumer advocates, led to a sort of "de-reponsibilization" of the insurance company, while the supervisory authority took the blame. Prior approval also appeared to be highly inefficient in all those situations where (as in case of a modification of legislation) a great number of policies had te be reviewed. Finally it was claimed that the system was hampering innovation.

Without awaiting the 1994 deadline imposed by the third directives, the Act of 19 July 1991 did away with the system of "contrôle a priori", to replace it by a system of "contrôle a posteriori". Undertakings do no longer need the prior approval of their policy conditions before they are allowed to market them. However, they are still required to communicate policy conditions and other documents (and premium rate scales), so that the supervisory authority can check them on their legality. The reason why administrative control is desirable, next to the judicial control by the courts, is not really explained. ${ }^{39}$

\footnotetext{
${ }^{39}$ While the requirement of an ex ante administrative authorization is a well-known technique of administrative law, the concurrent "jurisdiction" of both judicial and administrative authorities which arises in a system of ex post supervision tends to lead to complicated conflicts and legal problems. When the Office of Insurance Supervision judges that some clauses in the policy conditions of an - ex hypothesis - existing insurance contract (or any other contractual or publicitary document) are contrary to the laws and regulations, the Office can order withdrawal or adaptation of the document in question (art. 21 bis of the Insurance Supervision Act of 9 July 1975). In addition to conferring important powers upon the administrative supervisory authority, the new legislation of July 1991 also innovated by introducing an original type of civil sanction for the use of illegal clauses in an insurance contract. Article 19 bis of the Insurance Supervision Act stipulates that all such clauses will be deemed to have been drawn up in conformity with the Insurance Supervision Act right from the time of conclusion of the contract. The traditional sanction of nullity (of the illegal clause) is replaced by rather new sanction, which can be characterized as a system of "legal conversion": while invalidating the illegal clause, the law simultaneously "converts" the illegal and void clause into another, valid one, the contents of which are dictated by the legal provisions. How this kind of conversion will function in practice remains to be seen.
} 


\section{Concluding "hesitations"}

One thing is clear: the newly introduced regime of "contrôle a posteriori" and "contrôle de la rentabilité" appears to be miles away from the deregulatory approach toward insurance and insurance supervision, which Professor Reimer Schmidt thought to be typical of present day thinking about insurance supervision. While giving the impression of introducing relaxation in the control mechanism, the "contrôle de la rentabilié" would seem to rather increase the grip of supervisory authority upon the undertakings. For the authors of the present paper this does not mean that the new system should be condemned. The old system of prior approval of insurance conditions was certainly to be condemned because of the "de-responsabilization" effect upon the undertakings. The basic idea of the newly introduced system, namely that a sufficient premium rate scale constitutes the best guarantee for the solvency of the undertakings, is undoubtedly sound. However, some more critical remarks are in place, and a delicately balanced judgment must be made.

First it would appear that many of the (critical) questions which can be asked from the standpoint of economic theory about any kind of regulation and particularly about the old system of complete and ex ante supervision, remain very much valid with respect to the newly introduced system. It may be true that the danger of insufficient product innovation and differentation is considerably smaller under the new system, where the launching of new products is not submitted to any prior approval by the supervisory authority any more. But it remains so that the new system does not eliminate or diminish any more than the old one the dangers of effective lobbying by the industry. ${ }^{40}$ The most significant question concerns in our view the basic idea according to which no single (insurance) product should be sold at a loss. Apart from the practical problems related to the allocation of overall costs to any given single product or product group (problems which seem to have been handled by the described system in a satisfactory way), serious questions are raised about the economic justification of the prohibition of sales at loss prices. ${ }^{41}$ Besides, there is also the legal question whether this approach is in accordance with the basic doctrine of the E.C. (third generation) directives which, (although being not very explicit) would seem to solely rely on global financial control. In his already mentioned article, Bernard Dubuisson expresses some doubts :

"Dans la conception communitaire, la coordination des éléments essentiels du calcul des provisions techniques et des règles de placement est le seul garant de la sécurité des produits. Dès lors que la solvabilité l'entreprise n'est pas atteinte, une compagnie d'assurance doit pouvoir pratiquer une politique de tarification sans contrainte, éventuellement en dessous de l'équilibre technique, et compenser les pertes éventuelles par des résultats finan-

40 We refer quite generally to the economic theory of regulation, which claims that the economic regulation, instead of being based on the public interest, quite often serves the private interests of politically effective lobbying groups, see Van den Bergh, R., "Belgian Public Policy towards the Retailing Trade", in Law and economics and the economics of legal regulation (Eds. Graf M. von der Schulenburg and G. Skegh), Kluwer, Dordreeht, 1986, pp. 185 - 205.

41 Van den Bergh, R., o.c., 195. 
ciers sur les valeurs représentatives des provisions ou, ce qui est plus grave, par des prélèvements sur fonds propres (revenus du patrimoine libre)" ${ }^{42}$

There are also questions concerning the efficiency of the system. As was said before, the success of the system depends to a large degree upon the adequacy of the data-gathering. It could very well be that the system suffers more than an excess from a shortage of data. And even in the case of adequate data-gathering and analysis, there remains the problem of the implementation of the decisions of the supervisory authority.

Whereas the old system threatened to take away responsibility from the undertaking, the question is whether the new system does not overinvolve the supervisory authority, and by doing so, also shifts responsibility to the supervisory authority. In any event, some would argue that excessive data-gathering threatens the "privacy" of the undertaking and that control takes here a degree of intensity which makes the supervision look more like guardianship.

${ }^{42}$ Dubuisson, op. cit., No. 31, p. 1094. The author adds (rightly, we think): "Le financement des pertes techniques par des résultats financiers et les plus-values des placements correspondant aux provisions techniques, largement pratiqué par les entreprises d'assurance jusqu'à présent, ne constitute pas cependant une politique durable". 